\title{
Konstruktionsgrammatik, regler og funktionsbaseret struktur i neurokognitiv belysning
}

\author{
Kasper Boye \& Peter Harder
}

\begin{abstract}
This paper outlines a unified understanding of the grammar-lexicon contrast and its neurocognitive underpinning, which builds on and integrates three recent theories: 1) a functional linguistic theory of the grammar-lexicon contrast; 2) a functional theory of neural structure; 3) a theory of procedural and declarative memory. The proposed model is contrasted with Generative Grammar and in particular with Construction Grammar.
\end{abstract}

Nøgleord: Grammatik, leksikon, neurokognitiv videnskab, funktionel lingvistik

\section{Indledning}

Denne artikel tager udgangspunkt i en funktionel og kognitiv-lingvistisk teori om hvad der er det særlige ved grammatik (Boye \& Harder 2012), og i spørgsmålet om hvorvidt denne lingvistisk motiverede teori kan vises at have en neurokognitiv modsvarighed. Vi behandler dette spørgsmål med reference til to teorier om neurokognitiv arkitektur. Den ene er Jesper Mogensens såkaldte REF-model (Reorganisering af Elementære Funktioner) for hvordan hjernen bærer sig ad med at genskabe neurokognitive færdigheder (fx Mogensen 2011). Den anden er Ullmans teori om det deklarative og det procedurale system i hjernen (Ullman 2001, 2004; Ullman et al. 1997).

Med disse udgangspunkter vil vi i denne artikel prøve at vise vejen frem imod en teori der i relation til såvel lingvistikken som den neurokognitive videnskab giver mulighed for at give grammatikken både den særstatus den bør have, og den forbundethed med resten af systemet den også bør have. 


\section{Baggrund}

I dette afsnit vil vi kort ridse to af de centrale forudsætninger op for diskussionen i artiklen. Det drejer sig dels om den diskussion om neurokognitiv arkitektur der har udspillet sig mellem generativ og funktionel lingvistik, og dels om den teori vi tidligere har foreslået, om hvordan man kan forstå det særlige ved grammatik inden for en funktionel ramme.

Spørgsmålet om hvad grammatik er, har været forbundet med det neurale underlag siden Chomsky lancerede tesen om medfødthed. Grammatikkens særstatus er knyttet til tesen om et medfødt modul (jf. bl.a. Curtiss 2013; Berwick \& Chomsky 2016). Kognitiv-funktionelle lingvister har omvendt fokuseret på at kritisere denne særstatus og har understreget alle parallellerne mellem leksikon og grammatik, fx i relation til grammatikalisering: Hvis grammatiske størrelser historisk opstår ved forvandling af leksikalske størrelser, kan de ikke være væsensforskellige fra dem.

Den neurokognitive modsvarighed til denne orientering imod at sige at der ikke er væsensforskelle på grammatiske og andre færdigheder, er en arkitektur baseret på parallel og distribueret processering, også kendt under navnet konnektionisme. Konnektionistiske modeller fremhæver betydningen af at se hjernen som et funktionelt integreret system baseret på netværker (Rumelhart \& McClelland 1986; Rogers \& McClelland 2014). Kognitive opgaver løses ved konnektivitet mellem mange forskellige dele af systemet, uden at der er nogen direkte funktionel opkobling mellem opgaven og bestemte dele af hjernen, og drives af rene feedbackmekanismer (back-propagation). Denne enhedsmekanisme som forklaringsmodel for komplekse kognitive funktioner er af generativister blevet sammenlignet med en rent behavioristisk tilgang til kognitiv funktion. Den funktionelt-kognitive lingvistik har imidlertid også på det neurale område generelt orienteret sig imod en opfattelse baseret på at der ikke er en opdeling i to forskellige mekanismer (dual mechanism), men tværtimod en fælles mekanisme der omfatter både det grammatiske og resten af sproget (jf. Dabrowska 2004). Der foreligger imidlertid ikke en samlet beskrivelse af hvordan denne enhedsmekanisme kan håndtere veldokumenterede forskelle på grammatiske og leksikalske størrelser (bl.a. i forbindelse med afasi og andre sprogforstyrrelser).

Den klassiske modulære teori fremtræder i den nuværende situation heller ikke overbevisende, bl.a. fordi der er voksende evidens for at de egenskaber som et medfødt modul skulle forklare, nu kan forklares ad anden vej (fx Ibbotson \& Tomasello 2016). Modul-teorien kan desuden ikke forklare hvorfor og hvordan grammatik-beherskelse i nogen grad kan gendannes efter læsioner (jf. Mogensen 2014). Der er derfor behov for en teori der på 
én gang kan vise hvordan det neurokognitive system der giver grammatisk beherskelse, er en del af et større hele - og samtidig på hvilken måde det har sine egne særlige egenskaber.

Det lingvistiske udgangspunkt for forsøget på at løse denne opgave er en teori om grammatikken som en side af sproget med en særlig status. Teorien er fremstillet i Boye og Harder (2012) og har følgende hovedpunkt:

Grammatiske størrelser har to egenskaber der adskiller dem fra leksikalske:

- De er sekundære mht. prominens - det er leksikalske størrelser der er beregnet til at indkode det primære indhold.

- De er derfor også dependente i forhold til deres værtsudtryk (i nese-r er - $r$ dependent i forhold til nese).

Disse to egenskaber betyder at man ikke kan håndtere grammatiske størrelser uden at kunne kombinere dem med deres leksikalske værter da disse dels er distributionelt forudsatte, dels er bærere af det primære indhold.

Denne beskrivelse omfatter ikke kun forholdet mellem leksikalske rødder og grammatiske affikser, men også de grammatiske størrelser der har karakter af abstrakte kombinationsmønstre med åbne leksikalske pladser. Man kan som eksempel tage interrogativ sætningsstruktur: Man kan ikke stille et spørgsmål uden at fylde leksikalsk materiale ind i de pladser der indgår i konstruktionen, og det er dette leksikalske materiale der angiver det primære indhold i spørgsmålet.

Den neurokognitive baggrund for det alternative fundament vi vil præsentere her, er Mogensens REF-model. Modellen bygger på den centrale forestilling at neurokognitiv håndtering af funktionalitet kan forklares ved henvisning til tre niveauer af neural organisering. De to udgør yderpunkter i processen fra nervecelle til funktionel beherskelse. Ét af dem er direkte relateret til opgaveløsningen i yderverdenen og har neuralt set karakter af "overflade": I hvor høj grad formår det kognitive system at løse bestemte opgaver (f.eks. at beskrive Småkagetyveriet, en tegning der bruges til at elicitere afatisk tale), og hvilke træk kan man beskrive ved den måde opgaven bliver løst på? Det andet yderpunkt er direkte knyttet til selve nervevævet. Det omhandler de såkaldte "elementære funktioner" der er knyttet til bestemte grupper af nerveceller.

Imellem disse to yderpunkter ligger et niveau som omhandler organiseringen af samspillet mellem forskellige grupper af nerveceller med henblik på at løse bestemte opgaver. Det er her muligheden for genetablering efter traumer hører hjemme. De elementære funktioner der er direkte knyttet 
til væv der er gået tabt, kan ikke retableres. I det omfang disse elementære funktioner var underlag for "overfladeniveauet", kan man således ikke fortsætte med at benytte den opgaveløsningsmetode man havde før traumet. Det man kan, er dels at optræne andre nerveceller til at løse samme opgave, dels at forbinde forskellige nervegrupper på nye måder. Systemet forudsætter derfor som en grundlæggende egenskab en høj grad af plasticitet (jf. Mogensen 2011).

Af særlig interesse fra et funktionelt-kognitivt synspunkt er sondringen mellem to måder hjernen kan løse funktionelle opgaver på. Den ene og mere simple kaldes en "algoritmisk strategi": Den er organiseret udelukkende ud fra den helt konkrete opgave, og den har karakter af at man skaber en ny rutine. Som eksempel kan man tage det at binde snørebånd på sine sko. Efterhånden som man lærer dette, indarbejdes en bestemt rutine, som aktiveres på samme måde hver gang.

Den anden, som gælder mere komplekse færdigheder, har karakter af at opgaveløsningen falder i forskellige afdelinger, som ikke alle benyttes på samme måde i alle tilfælde, og som kan kombineres på forskellige måder. De kognitive under-strukturer der dannes i sådanne tilfælde, kalder Mogensen "algoritmiske moduler". ${ }^{1}$ Det interessante ved dem er at de ikke har en éntydig relation til en bestemt konkret opgave såsom at binde snørebånd, og et algoritmisk modul er således ikke i sig selv brugbart når man står med et konkret problem. Til gengæld kan de indgå i løsningen af flere forskellige opgaver, vel at mærke når de kombineres med andre sådanne sub-moduler (den betegnelse vi i det følgende vil benytte for "algoritmiske moduler"). Man kan som illustration tænke sig evnen til at reparere en bil. Hvor det at åbne kølerhjelmen for en rutineret mekaniker kunne være en algoritmisk strategi, er der ikke nogen fast procedure man bare kan køre igennem når man som almindelig bilejer skal kaste det første blik på sin nye bils motor: De forskellige håndbevægelsesrutiner må kombineres på en måde der svarer til den helt konkrete åbningsmekanisme.

Den grundlæggende tanke i syntesen mellem REF-modellen og funktionel lingvistik er (jf. Mogensen et al., under bedømmelse) at grammatiske systemer kan forstås som algoritmiske moduler: De opstår som en måde at strukturere løsningen af sproglige opgaver på, men man kan ikke løse nogen konkret opgave alene med grammatik - det skal kombineres med andre størrelser, ikke mindst leksikalsk indhold. Deres relative adskilthed fra

1. Forestillingen om at moduler kan dannes i stedet for at være medfødte, findes også i den funktionalistiske tradition i lingvistikken (jf. Elizabeth Bates 1999). 
hinanden skyldes altså ikke at man er født med dem som et særligt modul - den er tværtimod et slutprodukt, som skyldes at en komplet beherskelse af et sprog er en uhyre differentieret færdighed hvor man skal beherske og kombinere mange forskellige elementer. Denne teori er således ususbaseret, samtidig med at den kan sætte fingeren på hvad der er det særlige ved grammatikkens rolle i den samlede sprogfærdighed.

Ullmans teori, det andet teoretiske udgangspunkt, er en mere specifik teori om to neurale systemer og deres bidrag til sprogbeherskelsen. Det særlige ved denne teori er i en lingvistisk sammenhæng at den giver et bud på hvorved grammatisk kombinationsevne neuralt set adskiller sig fra evnen til at huske leksikalsk stof.

\section{Konstruktionsgrammatikken og sondringen mel- lem leksikon og grammatik}

Funktionel sprogvidenskab og herunder i særdeleshed konstruktionsgrammatik har til en vis grad defineret sit forskningsprogram i polemisk modsætning til generativ grammatik og derfor som nævnt fokuseret på at vise at sammenhængen mellem grammatikken og resten af sproget var stærkere end man kunne rumme i generativ teori.Konstruktionsgrammatikkens beskrivelsesformat er en liste over alle sprogets udtryk, inklusive de grammatiske. Forskellen i forhold til den traditionelle niveauadskillelse i fonologi, syntaks og semantik illustreres diagrammatisk i Croft \& Cruse (2004: 227, 247, 256): Niveauerne glider i baggrunden og afløses af et inventarium af enheder af forskellige størrelse (der inden i sig rummer egenskaber fra de forskellige niveauer). Dette inventariums status som en udvidelse af det gammelkendte format for leksikalsk viden, et leksikon, understreges af betegnelsen "konstruktikon" (benyttet bl.a. af Goldberg 2006: 64, med henvisning til Jurafsky 1996). Det rummer alle de enheder af udtryk og indhold som man må lære for at beherske sproget. Syntaktiske konstruktioner passer ind i en ususbaseret model på den måde at der er en meget direkte vej fra ususbaserede kollokative mønstre til deres konventionalisering i form af syntaktiske konstruktioner (jf. Bybee \& Hopper 2001; Bybee 2002), med hyppighed som en central faktor.

Det skal understreges at dette uden tvivl er en både legitim og givende måde at beskrive sprog på, og den har ikke mindst formået at tematisere egenskaber ved sproget som før var marginaliseret. Her tænkes især på den omstændighed at der har været en stor mængde egenskaber ved komplekse 
sproglige udtryk som ikke kunne opfanges i en polariseret beskrivelse, hvor der kun var to typer af relevante enheder: 1) helt abstrakte og generelle kombinationsregler og 2) helt faste ord og idiomer med invariant betydning. Samtidig er denne artikel dog baseret på den opfattelse at "konstruktikon"formatet ikke opfanger alle sprogets egenskaber.

Det der efter vores opfattelse mangler, er en fuldgyldig kognitiv-funktionel afløser af den rolle som grammatikken har - i modsætning til leksikon som middel til at kombinere sig frem til komplekse ytringer. Vi mener at forskellen mellem udtryk der findes på en allerede eksisterende liste, og udtryk som sprogbrugeren selv skal kombinere sig frem til, og især grammatikkens rolle som middel hertil, er væsentligere end det fremgår af det konstruktionsgrammatiske beskrivelsesformat.

Konstruktionsgrammatikere anerkender fuldt ud at muligheden for at danne et potentielt uendeligt antal sætninger af et finit antal elementer er en væsentlig egenskab ved menneskesprog (jf. Goldberg 2006: 11), og ligeledes at dette beror på evnen til at kombinere sig frem (Goldberg 2006: 22). Goldberg understreger tillige betydningen af det helt generelle niveau som generative regler fokuserer på - i modsætning til andre konstruktionsgrammatikere, som betoner det idiomatiske og idiosynkratiske, som konstruktioner bedre kan opfange end abstrakte regler. Der er således ingen principiel modstrid når det gælder eksistensen af abstrakte generelle skemaer og anerkendelsen af at sprog tillader kreative kombinationsmuligheder snarere end blot reproduktion af udtryk fra en afsluttet liste.

Kreativiteten og kombinationsmekanismen er imidlertid trådt i baggrunden. Disse egenskaber har status af 'muligheder' snarere end at indgå i selve sprogbeskrivelsen. Med til oplysningerne om hver enkelt konstruktion hører oplysninger om dens distributionspotentiale, dvs. på hvilken måde den kan kombineres med andre konstruktioner, hvis egenskaber derpå "arves" af det nye kombinerede udtryk. Den simpleste type af sådanne relationer er når et ord indsættes på en plads der er åben i en anden konstruktion, som når fx et adjektiv og et substantiv indsættes på pladsen i den abstrakte konstruktion $\mathrm{ADJ}+\mathrm{N}$.

Denne type relationer kan beskrive alle de samme kombinationsmuligheder som en kombinatorisk syntaks. De ting der ligner 'rene' kombinationsregler mest, er de maksismalt abstrakte skema-konstruktioner som 'adj + N' og 'ditransitiv konstruktion'. Beskrivelsesformatet har imidlertid den begrænsning at formatet er statisk. Man kan sammenligne det med et puslespil: Hver brik rummer information (i form af motivdele og kanternes form) om hvordan de kan kombineres med andre brikker, og på den basis 
kan man kombinere sig frem til større enheder. Hvis man antager at sproget er "constructions all the way down" (Goldberg 2006: 18), så har sprogbrugeren lært det hele når hun har en færdig liste over sprogets konstruktioner.

Det der mangler i billedet, kan illustreres med den situation man er i, når man har fået en pose med alle brikkerne til et puslespil. I en vis forstand er det fuldkommen korrekt at det er alt hvad man behøver - der er ingen oplysninger der mangler. Men det er på den anden side også klart at det at beherske et sprog, ikke er det samme som at have alle brikkerne.

Konstruktionsgrammatikken forudsætter - men har ikke i sig indbygget - en dynamisk, procedural mekanisme, der i sproget svarer til den mekanisme hvormed man sætter puslespilsbrikkerne sammen. I puslespilssituationen er det ikke fatalt hvis sådan en procedural anvisning mangler - fordi der ikke findes nogen fri kombinerbarhed, kun én løsning. Men i sproget findes der netop en mulighed for at kombinere sig frem til hele ytringer der ikke er givet på forhånd - og denne mulighed kan ikke fuldt ud begribes ved at henvise til egenskaber ved de enkelte brikker i spillet.

Hertil kommer at forskellen mellem grammatiske og leksikalske brikker nedtones mest muligt i konstruktionsgrammatikken (se fx Trousdale 2014). Det er i modstrid med neurokognitive forskning der peger på at konstruktionsgrammatikkens "kontinuum" mellem leksikon og grammatik ikke får alt med (se Pulvermüller et al. 2013).

Ovenfor beskrev vi som noget karakteristisk ved grammatiske størrelser at de ikke kan stå alene, men er dependente i forhold til et værtselement. Dependens i den forstand det drejer sig om, betyder "obligatorisk procedural opkobling”. Det gælder således at beherskelse af grammatiske elementer er bundet op på en procedure der skal udføres for at de kan bruges. Denne opkoblingstvang er et grundtræk ved menneskesprog: For at beherske et menneskesprog skal man kunne sætte udtryk sammen, ligesom man skal kunne sætte puslespilsbrikker sammen for at lægge puslespil.

Det er dette træk der ikke er tydeligt nok beskrevet hvis man kun beskriver et grammatisk udtryk som en "konstruktion" på linje med alle andre. De grammatiske elementer i sproget skal ganske rigtigt være en del af lageret, som konstruktionsgrammatikken understreger - men sprogevnen kræver mere end blot at man kan hente dem frem fra lageret. 


\section{Det deklarative og det procedurale system}

I sin generelle form er sondringen mellem deklarativ og procedural hukommelse velkendt. Den deklarative hukommelse er den man normalt forbinder med ordet hukommelse. Det er det sted hvor man lagrer ting man oplever eller får at vide. Den procedurale hukommelse kendes også under betegnelsen "muskelhukommelse" eller ud fra sloganet "kroppen husker!". Det mest slående ved procedural hukommelse er at den ikke er forbundet med bevidst indhold, men i stedet sætter en i stand til at gøre ting man en gang har lært at gøre. Et klassisk eksempel er at køre på cykel: Når man først har lært det, husker man det - uden dog at vide eller kunne forklare hvad det er man husker. Derfor kan deklarativ hukommelse også kaldes "eksplicit", og procedural hukommelse "implicit" hukommelse. Deklarativ hukommelse er med andre ord stedet for viden, på engelsk knowing-that, mens procedural hukommelse er stedet for kunnen, på engelsk knowing-how.

Deklarativ hukommelse dækker både det man har kaldt "semantisk" og "episodisk" hukommelse. De to typer af erindring er forskellige i deres placering på en skala fra det helt konkrete til det abstrakte, men har det tilfælles at de kan genkaldes som eksplicit bevidsthedsindhold. Forskellen går således mere på hvilken karakter den erindrede genstand har, end på det kognitive lager de er anbragt i. Dermed passer den deklarative hukommelse også bedst til at huse fænomener af den art som hører hjemme under grundbegrebet i kognitiv lingvistik, nemlig konceptuelle størrelser. Disse findes forskellige steder på skalaen: Eksemplarer hører til i den mest konkrete ende, basisbegreber er destilleret ud af den slags genstande som man møder mest i erfaringen, og de mest skematiske begreber som "entitet" eller "artefakt" hører hjemme langt henne i den mest abstrakte afdeling - men alle har et indhold som man kan kalde frem for bevidstheden.

Procedural hukommelse er tæt knyttet til bevægeapparatet. Som ved eksemplet med at cykle gælder det generelt at alle de færdigheder der er knyttet til fysisk handling, lagres i procedural hukommelse.

Ullman har opbygget et forskningsprogram omkring sprogets relation til det deklarative og det procedurale system (se Ullman 2001; 2004; 2016). Eftersom de to systemer på mange måder er velkendte i andre sammenhænge end sproglige og der foreligger en temmelig righoldig viden om dem (blandt aspekterne er forskelle mellem kønnene, relationer til sprogforstyrrelser og reaktion på forskellige medikamenter, jf. Ullman 2016), kunne man forvente at denne viden også havde manifesteret sig i en veludbygget viden om de to systemers rolle for sproglige forhold. Når dette ikke i så høj grad er tilfældet, har det ifølge Ullman (2016) at gøre med den "isolationistiske" 
tilgang til forskning i netop sproglige forhold - dvs. at man i for høj grad har interesseret sig for det specifikt sproglige i stedet for at se på hvordan sproget trækker på mekanismer der ikke er specifikt rettet imod sprog.

Fra et lingvistisk synspunkt kunne dette virke som en markering af afstandtagen til det generative forskningsprogram - men Ullman har samarbejdet med centrale forskerpersonligheder med tilknytning til generativ grammatik, herunder Steven Pinker (jf. Ullman et al. 1997; Pinker \& Ullman 2002). Et tema har her været at vise betydningen af forskellen mellem det deklarative og det procedurale system for at forstå forskellen mellem regelmæssige og uregelmæssige datidsformer i engelsk. Pinker \& Ullman (2002) baserer således deres argumentation på data der tyder på at uregelmæssige datidsformer lagres sammen med leksikonord i det deklarative system, mens regelmæssige datidsformer bedre kan forklares som hjemmehørende i det procedurale system. I denne sammenhæng kan det særegne ved det procedurale system således være egnet til at dokumentere det særlige ved grammatiske regler som noget andet end leksikalske størrelser.

Denne konstatering udgør imidlertid tillige et egnet grundlag for at vise på hvilken måde en funktionel og ikke-modulær tilgang til det særlige ved grammatik kan knytte an til Ullmans forskningsprogram. Hvad denne argumentation viser, er nemlig nok at der er forskel på leksikonord og grammatiske regler - men ikke at forskellen kan tilskrives et særligt grammatisk modul (jf. citatet fra Ullman 2016 ovenfor). Det procedurale system er således ikke modulært, men forbundet med en lang række andre systemer i hjernen og i den menneskelige adfærd. Ligesom det deklarative system er det procedurale system desuden evolutionært langt ældre end sprogevnen. Det er således et godt eksempel på kognitiv-funktionel lingvistiks generelle påstand om at sprogevnen i hjernen, snarere end at bero på et specifikt og indkapslet modul støtter sig på eksisterende neurale systemer der også tjener andre formål.

\section{Den integrerede model for lingvistisk og neuro- kognitiv struktur}

Et vigtigt fællestræk på de to teoriområder som vi argumenterer for at man kan integrere, er at teorierne på begge områder er usus-baserede og funktionsbaserede. Det er det som sproget bruges til, der er basis for dannelsen af sprogstruktur - og det er det som hjernen bruges til, der er basis for dannelsen af neurokognitive strukturer der implementerer opgaveløsningen. Samtidig er det afgørende at denne funktionelt baserede teori 
på begge områder ikke hævder den en-til-en-relation mellem funktion og struktur som ofte opfattes som et fældende argument imod en funktionel sprogopfattelse: Strukturen kan ikke udledes direkte af funktionen, fordi løsningen af komplekse opgaver kræver komplekse strukturer.

På den neurale side udgør REF-modellen det strukturelt overordnede niveau i forhold til Ullmans model: Teorien om funktionelt betingede strategier og moduler kan anvendes ikke kun på sprog og på samspillet mellem det procedurale og deklarative system, men generelt på alle processer der involverer udvikling og differentiering af neurokognitive funktioner. Ser vi specifikt på REF-modellens anvendelse, kan modellens hovedtræk opridses som følger:

De to systemer er et eksempel på at hjernen ikke er det forskelsløse netværk af processorer som ville svare til en ren PDP-model - hvor alle processorer er involveret $\mathrm{i}$ alt, og hvor det kun er et spørgsmål om at have et system der er stort nok til at kunne håndtere et vanskeligt område som sprog. Hjernen har forudeksisterende, evolutionært betingede systemer som sproget trækker på og som er med til at bestemme hvor i hjernen sproglige funktioner typisk lokaliseres. Den klassiske relation mellem Brocas område og sprog er et eksempel, og det passer ind i teorien derved at Brocas område har en vigtig rolle ${ }^{2}$ i det procedurale system (jf. Ullman 2004, 2013).

Med den præ-eksisterende neurale arkitektur som udgangspunkt kan hjernen imidlertid udvikle nye strukturer der opstår som respons på funktionelle krav, dels unikke "strategier" til helt konkrete opgaver (snørebåndene), dels funktionelt baserede "moduler" til at løse opgaver der indgår i mere komplekse funktionelle systemer. Samspillet mellem det procedurale og det deklarative system i implementeringen af sproglig kunnen kan forstås som noget der involverer dannelsen af sådanne moduler.

Moduldannelse er især relevant for at forstå grammatikkens rolle i sprog. Grammatik er ikke i sig selv anvendelig til at løse funktionelle opgaver, fordi grammatiske elementer, jf. ovenfor, er kendetegnet ved at være sekundære og dependente i forhold andre elementer - i sidste ende i forhold til leksikalske, potentielt primære elementer. Grammatik er resultatet af en højt differentieret udtryksevne i forhold til kommunikationssystemer hos andre arter, hvis signaler har holofrastisk karakter (ét tegn svarer til én meddelelse), og derfor kan grammatik ikke rummes i en en-til-en-relation mellem en

2. Men også børn der mangler den ene hemisfære, herunder Brocas område, kan lære sprog, jf. Danelli et al. (2013). En medfødthedshypotese der bygger på neuroanatomisk lokalisation, kan altså ikke opretholdes. 
bestemt kommunikativ opgave og en neural implementering. Men omvendt gælder det at ikke alle sproglige meddelelser er grammatisk strukturerede. Holofraser som av findes også som del af menneskesprog, og de kan også hos mennesker fungere ved en direkte funktionel tilkobling uden at være afhængige af submoduler der også tjener andre formål.

Denne artikels pointe kan nu opsummeres:

Den rent lingvistiske teori vi har fremsat om grammatik, siger at grammatik er en hjælpefunktion, der gør det muligt at udtrykke komplekse meddelelser. Grammatik er altså funktionelt motiveret - uden at være bærer af den primære funktion en meddelelse skal tjene - og grammatiske størrelser kan derfor ikke optræde alene, men kun som tjener for leksikalsk indhold.

Den neurokognitive teori vi har allieret os med, siger at hjernen er skabt til at opbygge neurokognitive subsystemer der sætter hjernens ejer i stand til at løse funktionelle opgaver. En således erhvervet evne til at løse opgaver kan enten være unikt implementeret i en bestemt rutine der løser en ganske bestemt opgave og kun den - eller også kan den bero på et komplekst neuralt system med submoduler der indgår i flere forskellige funktioner, men ikke selv alene kan løse nogen opgaver.

Den integrerede teori siger at evnen til at udtrykke grammatisk komplekse ytringer beror på et neurokognitivt system med sub-moduler som opstår ved at hjernen rekrutterer de mest egnede eksisterende neurale systemer til at håndtere grammatisk kompleksitet. Sådanne submoduler behøves ikke ved holofraser som av, men de behøves fx når man skal danne en interrogativ sætning, hvor man skal kombinere en bestemt ledfølge med et bestemt leksikalsk indhold.

Analogien mellem de krav der stilles for at kunne tale et sprog og for at kunne lægge puslespil (at man skal kunne sætte ting sammen) er ud fra denne betragtning ikke helt tilfældig: Begge dele stiller krav til det procedurale system, med dets tætte tilknytning til bevægeapparatet. Det at de to færdigheder trækker på de samme præ-eksisterende systemer, er på den anden side ingen garanti for at hvis man kan dette ene, så kan man også det andet. I begge tilfælde skal der ske en neural organisering af disse systemer som tager form af rutiner og submodulære delkompetencer der er indrettet på de opgaver hvis løsning udgør den funktionelle motivation.

Argumentationen ovenfor har sigtet på at vise at det særligt grammatiske kan håndteres ved en teori hvor centrale lingvistiske egenskaber ved grammatiske i modsætning til leksikalske størrelser må forstås i kraft af deres særlige neurale egenskaber. Blandt disse er dels deres opkobling på det procedurale system (fordi grammatik involverer størrelser der skal 
kombineres med andre for at kunne fungere), dels deres implementering i submoduler der ikke er direkte bundet op på løsningen af en konkret funktionel opgave.

Tilbage står en redegørelse for hvordan man kan forestille sig forholdet mellem det procedurale og det deklarative system i den integrerede model der er lagt op til. Set i forhold til kognitiv lingvistik er det deklarative systems rolle det mindst problematiske: Den består i at indoptage og lagre de erfaringer, herunder den sproglige usus, som ifølge den ususbaserede tilgang udgør grundlaget for sprog. I det omfang et sprog er 'et struktureret inventar af konventionelle sproglige størrelser' (Langacker 2008: 222), må dette inventars kognitive hjemsted være den deklarative hukommelse.

Dette ville svare til en antagelse om at den grundlæggende formel for integrationen mellem de to systemer ville være en neural infrastruktur der består $i$ at den procedurale afdelings opgave er at levere lagrede kombinationsprocedurer som afhenter de størrelser der er lagret i den deklarative afdeling. Selvom vi mener at dette er en grundlæggende rigtig antagelse, er det klart at helt så simpelt er det ikke.

Her kommer diskussionen om »dual mechanism« ind i billedet. De kognitive lingvisters indvending imod den radikale adskillelse mellem grammatik og leksikon spiller også ind i denne sammenhæng. Bl.a. er spørgsmålet om grammatikalisering stadig en udfordring: Hvordan kan størrelser gå over fra det deklarative system til det procedurale hvis der er en uoverstigelig kløft imellem de to?

Ullmans seneste forskning (Nevat et al., under udgivelse) tyder på at der er et vist overlap mellem de ting der lagres i deklarativ og procedural hukommelse. Således vil regelmæssige kombinationer både kunne lagres i den deklarative og i den procedurale hukommelse. Dette tilbyder et neurokognitivt underlag for Langackers pointe (1987: 42) med at tale om 'the rule/list fallacy': Der er ingen grund til at antage at samme form ikke kan have status både af resultatet af anvendelsen af en produktiv regel og af at være en lagret form. Undersøgelse af neural aktivering under indlæring af et kunstigt bøjningssystem (Nevat et al., under udgivelse) viser således et mønster hvor den procedurale hukommelse er stærkest aktiveret ved ikke-trænede former, og mindst ved trænede former med høj hyppighed: Dette kunne passe med at formen eksisterer i begge systemer og at den deklarative hukommelse dominerer når først kombinationen får status af et kendt komplekst udtryk, snarere end som noget man skal kombinere sig frem til uden at have hørt det før.

Et andet udslag af samme forhold er at noget tyder på at L2-talere gør 
større brug af det deklarative system end L1-talere (jf. Bowden et al. 2010). Dette understreger også at automatisering må forstås i relation til det procedurale system, snarere end blot det deklarative: Fuld indfødt beherskelse betyder at man kan overlade mere til den implicitte autopilot.

Dette element af overlap mellem systemerne tilbyder en basis for en neurokognitiv redegørelse for grammatikalisering: Grammatikalisering af leksikalske udtryk kunne tænkes at involvere en neurokognitiv proces med to elementer: Et oprindeligt leksikalsk udtryk (fx spansk -mente 'sind' der bliver til en adverbialmarkør lentamente) bliver tættere forbundet med den kombinationsprocedure der knytter det til en leksikalsk vært - og bliver derfor gradvis stærkere knyttet til den procedurale hukommelse. Samtidig mister det mere og mere af den konceptuelle substans der er knyttet til dets plads i det deklarative lager. Hvis man som et rent tankeeksperiment forestiller sig at kunne få det frem på en hjernescanner, ville det lyse mere og mere op i det procedurale system og blive mere og mere afdæmpet $\mathrm{i}$ det deklarative system.

Den model vi har foreslået, bevarer altså de dele af dikotomien mellem grammatiske og leksikalske størrelser som afspejler at de to har forskellige roller - men den fastholder ikke en absolut dikotomi. Leksikalske udtryk har en særlig tilknytning til det deklarative system derved at de som potentielt primære størrelser (i et eller andet omfang) kan stå alene. Grammatiske størrelser har en særlig tilknytning til det procedurale system derved at de som sekundære størrelser forudsætter en mekanisme der knytter dem til andre, leksikalske størrelser. Men teorien forudsiger at også grammatiske størrelser kan være deklarativt repræsenteret (hvad der bl.a. er nyttigt ved fremmedsprogsindlæring), selvom de ikke er fuldt operationelle alene i kraft af deres status som en del af det deklarative lager. Den forudsiger tillige at leksikalske størrelser er opkoblet på de procedurer der tillader dem at optræde i kombination med grammatiske størrelser - selvom sprogbrugeren kan vælge at ignorere denne opkobling og nøjes med at sige fx mål!

\section{Konklusioner}

Denne fremstilling kan i sagens natur kun få et programmatisk præg. På trods heraf mener vi der er tilstrækkelig substans på både den neurale og den lingvistiske side til at der fremstår et klart alternativ til den ufrugtbare polarisering mellem på den ene side den radikale generative adskillelse mellem rent formelle regler og leksikalsk indhold og på den anden side den kognitive og især konstruktionsgrammatiske orientering imod at se sprog 
som bestående udelukkende af et inventar, uden plads til at grammatiske størrelser og kombinationer har en særlig rolle inden for helheden.

Den integrerede model vi har skitseret, rummer følgende centrale træk:

(1) Den indebærer en ususbaseret arbejdsdeling mellem leksikalske og grammatiske udtryk og en ususbaseret neurokognitiv arkitektur der placerer de to typer udtryk forskelligt, men i et integreret system.

(2) Den neurale implementering af sprogevnen trækker på to forudeksisterende neurokognitive systemer: i) det procedurale system, som udgør fundamentet for kombinationsevnen, og ii) det deklarative system, som lagrer det konceptuelle indhold der er knyttet til sproglige udtryk.

(3) Det integrerede system trækker på både det procedurale og det deklarative system. Det er ikke nedarvet, men bygges op drevet funktionelt af de krav man skal leve op til for at kunne ytre sig i et givet sprogsamfund.

(4) Denne model indoptager en pointe fra dual mechanism-teorien derved at grammatiske kombinationer ikke kan forklares alene med henvisning til et lager (et leksikon eller konstruktionsgrammatisk konstruktikon).

(5) Samtidig tager den højde for de argumenter imod dual mechanismteorien der peger på at en radikal adskillelse ikke kan opretholdes, idet den indebærer et overlap og samspil imellem den proceduralt og den deklarativt funderede del af sprogbeherskelsens neurale implementering.

Den foreslåede models forhold til konstruktionsgrammatikken kan udtrykkes på følgende måde: Konstruktionsgrammatikken gør rede for den del af sproget som hører hjemme i det deklarative system, jf. følgende passus:

Usage-based proposals have been formulated in slightly differing ways by different researchers, but the essential point that both instances and generalizations over instances are stored remains the same. (Goldberg 2006: 64) 
Eller sagt på en anden måde: Konstruktionsgrammatikken gør rede for et sprog som et lager og ikke som en dynamisk kombinationsevne (med grammatikken i en anden rolle end leksikon). En sådan model kan vanskeligt stille et spørgsmål om hvorvidt helt abstrakte konstruktioner à la interrogativ sætningsstruktur faktisk er lagret i det deklarative system, eller de måske kun eksisterer som procedurer der kan aktiveres.

Under ét mener vi at den integrerede model der er foreslået i denne artikel, udgør et slagkraftigt alternativ både til de eksisterende tilgange til problemet i den funktionelt-kognitive lingvistik vi selv regner os til, og til den ufrugtbare polarisering i forhold til formel generativ lingvistik.

\section{Henvisninger}

Bates, E. (1999). Plasticity, localization and language development. I: The changing nervous system: Neurobehavioral consequences of early brain disorders. Broman, S. \& Fletcher, J.M. (red.), New York: Oxford University Press, 214-253.

Berwick, R.C. \& Chomsky, N. (2016). Why Only Us. Language and evolution. Cambridge, M.A.: MIT Press.

Boye, K. \& Harder, P. (2012). A usage-based theory of grammatical status and grammaticalization. Language 88, 1, 1-44.

Bybee, J. (2002). Sequentiality as the basis of constituent structure. I: The evolution of language out of pre-language. Givón, T. \& Bertram Malle (red.). Amsterdam: John Benjamins, 109-134.

Bybee, J.L. \& Hopper, P.J. (red.) (2001). Frequency and the emergence of linguistic structure. Amsterdam: John Benjamins.

Croft, W.A. \& Cruse, D.A. (2004). Cognitive linguistics. Cambridge: Cambridge University Press.

Curtiss, S. (2013). Revisiting modularity: Using language as a window to the mind. I: Rich languages from poor inputs. Piatelli-Palmarini, M. \& Berwick, R.C. (red.). Oxford: Oxford University Press, 68-90.

Dabrowska, E. (2004). Language, mind and brain: Some psychological and neurological constraints on theories of grammar. Edinburgh: Edinburgh University Press.

Dabrowska, E. (2010). Productivity, proceduralization and SLI: A Comment on Hsu and Bishop. Human Development 53, 276-284.

Danelli, L1, Cossu, G, Berlingeri, M, Bottini, G, Sberna, M, \& Paulesu, E. (2013).Is a lone right hemisphere enough? Neurolinguistic architecture in a case with a very early left hemispherectomy. Neurocase 19 (3): 20931. DOI: 10.1080/13554794.2011.654226. 
Goldberg, A. (2006). Constructions at work: The nature of generalization in language. Oxford: Oxford University Press.

Ibbotson, P. \& Tomasello, M. (2016). Evidence Rebuts Chomsky's Theory of Language Learning. Scientific American, 7. september, 2016.

Jurafsky, D. (1996). A probabilistic model of lexical and syntactic access and disambiguation. Cognitive Science 20, 137-94.

Langacker, R.W. (1987). Foundations of Cognitive Grammar, vol.1: Theoretical prerequisites. Stanford: Stanford University Press.

Langacker, R.W. (2008). Cognitive Grammar: A Basic Introduction. Oxford: Oxford University Press.

McClelland, J.L. \& Patterson, K. (2002). Rules or connections in past-tense inflections: What does the evidence rule out? Trends in Cognitive Sciences $6,11,465-472$.

Mogensen, J. (2011). Almost unlimited potentials of a limited neural plasticity: Levels of plasticity in development and reorganization of the injured brain. 7. Conscious. Stud. 18, 13-45.

Mogensen, J. (2012). Reorganization of Elementary Functions (REF) after brain injury: Implications for the therapeutic interventions and prognosis of brain injured patients suffering cognitive impairments. I: Brain damage: Causes, management and prognosis. Schäfer, A.J. \& Müller, J. Hauppauge, NY: Nova Science Publishers, 1-40.

Mogensen, J. (2014). Reorganization of Elementary Functions (REF) after brain injury and in the intact brain: A novel understanding of neurocognitive organization and reorganization. I: Horizons in neuroscience research, vol. 15, Costa, J. \& Villalba, E. (red.). New York: Nova Science Publishers, 99-140.

Mogensen, J. (2015). Recovery, compensation and reorganization in neuropathology - levels of conceptual and methodological challenges. I: Cognitive plasticity in neurologic disorders. Tracy, J.I., Hampstead, B.M. \& Sathian, K. (red.). New York: Oxford University Press, 3-28.

Mogensen, J., \& Malá, H. (2009). Post-traumatic functional recovery and reorganization in animal models. A theoretical and methodological challenge. Scand. J. Psychol. 50, 561-573.

Mogensen, J., Boye, K., Siebner, H.R. \& Harder, P. (Under bedømmelse). Integrating linguistics and neurocognitive organization: A function-based account of structural complexity.

Nevat, M., Ullman, M.T., Eviatar, Z. \& Bitan, T. (Under udgivelse). The neural bases of the learning and generalization of morphological inflection. Neuropsychologia. 
Pinker, S. \& Ullman, M. (2002). The past and future of the past tense. Trends in Cognitive Sciences 11, 1, 456-463.

Pulvermüller, F, Capelle, B. \& Shtyrov, Y. (2013). Brain basis of meaning, words, constructions, and grammar. The Oxford Handbook of Construction Grammar. Hoffmann, T. \& Trousdale, G. (red.), Oxford Handbooks Online, DOI: 10.1093/oxfordhb/9780195396683.013.0022.

Rumelhart, D. \& McClelland, J. (1986). Parallel distributed processing. Cambridge, MA: MIT Press.

Trousdale, G. (2014). On the relationship between grammaticalization and constructionalization. Folia Linguistica 48, 557-577.

Ullman, M., Corkin, S., Coppola, M., Hickok, G., Growdon, J.H., Koroshetz, W.J., \& Pinker, S. 1997. A neural dissociation within language: Evidence that the mental dictionary is part of declarative memory, and that grammatical rules are processed by the procedural system. Fournal of Cognitive Neuroscience 9, 289-299.

Ullman, M. (2001). The neural basis of lexicon and grammar in first and second language: the declarative/procedural model. Bilingualism: Language and Cognition 4, 2, 105-122.

Ullman, M. (2004). Contributions of memory circuits to language: The declarative-procedural model. Cognition 92, 1, 231-270.

Ullman, M.T. (2016). The declarative/procedural model: A neurobiological model of language learning, knowledge and use. I: Hickok, G. \& Small, S.A. (red.). The Neurobiology ofLanguage. Amsterdam: Elsevier, 953-68. 